ISTIGHNA, Vol. 3, No 1, Januari 2020 P-ISSN 1979-2824 E-ISSN 2655-8459

Homepage: http://e-journal.stit-islamic-village.ac.id/index.php/istighna

Bahruddin Zaini

Pembelajaran Pendidikan Agama Islam Pada Program Akselerasi

\title{
PEMBELAJARAN PENDIDIKAN AGAMA ISLAM PADA PROGRAM
}

\author{
AKSELERASI \\ Bahruddin Zaini \\ bahruddinzaini008@gmail.com \\ Institut Ilmu Keislaman Zainul Hasan Genggong Probolinggo
}

\begin{abstract}
The researcher aims to analyze the implementation of Islamic religious education learning in the acceleration program at SD State University Laboratory Malang which includes PAI learning planning in the accelerated program at SD LAB UM, the implementation of PAI learning in the acceleration program at SD LAB UM, and the evaluation of PAI learning in the acceleration program at UM LAB SD. Researchers use a qualitative approach, while the type of research uses case studies. The results of this study are the implementation of Islamic Education Learning in the acceleration program at SD Laboratory State University of Malang, Includes: First the planning of PAI learning in the acceleration program at SD LAB, there are three stages in this planning. implemented by P2LP. The second stage of preparation in which all teachers must be able to compile and make their own learning models. The third stage of development where the teacher must be able to develop learning devices. The implementation of PAI learning in the acceleration program in SD LAB starts from the selection of learning models. While the evaluation in the acceleration program is carried out continuously and continuously to obtain information about the progress and success of student learning.
\end{abstract}

\section{Keyword : Islamic education learning; acceleration program}

Abstrak: Peneliti bertujuan untuk menganalisis Implementasi pembelajaran pendidikan Agama Islam pada program akselerasi di SD Laboratorium Universitas Negeri Malang yang meliputi Perencanaan pembelajaran PAI pada program akselerasi di SD LAB UM, Pelaksanaan pembelajaran PAI pada program akselerasi di SD LAB UM, dan Evaluasi pembelajaran PAI pada program akselerasi di SD LAB UM. Peneliti menggunakan pendekatan kualitatif, sedangkan jenis penelitiannya menggunakan studi kasus. Hasil dari penelitian ini adalah implementasi Pembelajaran Pendidikan Agama Islam pada program akselerasi di SD Laboratorium Universitas Negeri Malang, Meliputi: Pertama perencanaan pembelajaran PAI pada program akslerasi di SD LAB, ada tiga tahapan dalam perencanaan ini pertama pelatihan pada awal semester semua guru wajib mengikuti pelatihan yang dilaksanakan oleh P2LP. Kedua tahap penyusunan dimana seluruh guru harus mampu menyusun dan membuat prangkat pembelajaran sendiri. Ketiga

Peer reviewed under reponsibility of STIT ISLAMIC VILLAGE.

(C) 2018 STIT ISLAMIC VILLAGE, All right reserved, This is an open access article under 65 the CC BY SA license (https://creativecommons.org/licenses/by-sa/4.0/) 
ISTIGHNA, Vol. 3, No 1, Januari 2020 P-ISSN 1979-2824 E-ISSN 2655-8459

Homepage: http://e-journal.stit-islamic-village.ac.id/index.php/istighna

Bahruddin Zaini

Pembelajaran Pendidikan Agama Islam Pada Program Akselerasi

tahap pengembangan dimana guru harus mampu mengembangkan perangkat pembelajaran. Pelaksanaan pembelajaran PAI pada program akslerasi di SD LAB dimulai dari pemilihan model pembelajaran. Sedangkan Evaluasi dalam program akselerasi dilakukan secara terus menerus dan berkelanjutan untuk memperoleh informasi tentang kemajuan dan keberhasilan belajar siswa.

\section{Kata Kunci: Pembelajaran Pendidikan Agama Islam; Program Akselerasi}

\section{A. PENDAHULUAN}

Menurut UU No. 20 Tahun 2003, tentang sistem pendidikan nasional bahwa

"Pendidikan adalah usaha sadar dan terencana untuk mewujudkan suasana belajar dan proses pembelajaran agar peserta didik secara aktif mengembangkan potensi dirinya untuk memiliki kekuatan spiritual keagamaan, pengendalian diri, kepribadian, kecerdasan, akhlak mulia, serta keterampilan yang diperlukan dirinya, masyarakat, bangsa dan Negara."

Pendidikan mempunyai peranan yang sangat menentukan bagi perkembangan dan perwujudan dari individu, terutama bagi pembangunan bangsa dan negara. Kemajuan suatu budayaan bergantung pada cara kebudayaan tersebut mengenali, menghargai dan memanfaatkan sumber daya manusia dan hal ini berkaitan erat dengan kualitas pendidikan yang diberikan kepada anggota masyarakatnya.

Pendidikan yang diharapkan bukan sebatas pemberian atau pentransferan ilmu dari pengajar kepada peserta didik saja, tetapi pendidikan yang mampu mengantarkan peserta didik menjadi pribadi yang unggul dan dapat menghadapi kehidupannya di masa yang akan datang secara cerdas, kreatif dan mandiri. Untuk menciptakan peserta didik yang unggul tersebut diperlukan pendidikan yang bermutu. ${ }^{2}$ Adapun pendidikan yang bermutu harus mencakup dua dimensi yaitu orientasi Akademik dan orientasi keterampilan hidup yang Esensial. Berorientasi akademik berarti menjanjikan prestasi akademik peserta didik sebagai tolak ukurnya. Sedangkan yang berorientasi keterampilan hidup (life skill) yang esensial adalah pendidikan yang dapat membuat peserta didik bertahan (survive) di kehidupan nyata.

\footnotetext{
${ }^{1}$ Undang-Undang No. 20 Tahun 2003 Tentang Sistem Pendidikan Nasional.

2 Direktorat Pendidikan Dasar dan Menengah dan Pembinaan Sekolah Luar Biasa,PedomanPenyelenggaraan Pendidikan Untuk Peserta Didik Bekecerdasan Istimewa (Jakarta: DepartemenPendidikan Nasional), hlm. 2
} 
ISTIGHNA, Vol. 3, No 1, Januari 2020 P-ISSN 1979-2824 E-ISSN 2655-8459

Homepage: http://e-journal.stit-islamic-village.ac.id/index.php/istighna

Bahruddin Zaini

Pembelajaran Pendidikan Agama Islam Pada Program Akselerasi

Agar sasaran peningkatan kualitas sumber daya manusia ini berhasil,diperlukan layanan pendidikan yang mempertimbangkan bakat, minat, kemampuan, kecerdasan peserta ddik. Hal ini sesuai dengan tujuan pendidikan pada umumnya yakni menyediakan lingkungan yang memungkinkan anak didik untuk mengembangkan bakat dan kemampuannya secara optimal. Sehingga ia dapat mewujudkan dirinya dan berfungsi sepenuhnya sesuai dengan kebutuhan pribadinya dan kebutuhan masyarakat.

Sementara itu pelayanan pendidikan yang dilaksanakan selama ini masih bersifat massal, artinya memberikan layanan yang sama kepada seluruh siswa. Sehingga kurang memperhatikan perbedaan antar peserta didik dalam kecakapan minat dan bakatnya. Selain itu, penyelenggaraan pendidikan selama ini masih berorientasi pada aspek kuantitas, yakni untuk dapat melayani sebanyak mungkin jumlah peserta didik. Sedangkan yang menjadi isu kelemahan saat ini adalah belum terakomodasinya kebutuhan individual siswa.

Perhatian khusus pada peserta didik yang berpotensi cerdas atau bakat istimewa sesuai dengan fungsi utama pendidikan, yaitu mengembangkan potensi peserta didik secara utuh dan optimal.

Salah satu koridor pelayanan pendidikan bagi peserta didik yang memiliki kemampuan dan kecerdasan luar biasa adalah melalui program akselerasi (percepatan belajar). Sebagaimana dikatakan E. Mulayasa Menyediakan programprogram khusus sebagai usaha untuk penanganan anak berbakat diantaranya adalah dengan diselenggarakannya program akselerasi sebagai layanan terhadap perbedan perorangan dalam diri siswa. ${ }^{3}$

Program akselerasi atau program percepatan merupakan suatu program untuk peserta didik yang memiliki tingkat kecerdasan luar biasa atau dengan kata lain program untuk mempercepat masa studi bagi peserta didik yang memiliki tingkat kecerdasan tinggi yang berhak untuk mendapat perhatian khusus agar

${ }^{3}$ E. Mulyasa, Kurikulum Berbasis Kompetensi, (Bandung: PT Rosdakarya, 2004), Hlm. 128 
ISTIGHNA, Vol. 3, No 1, Januari 2020 P-ISSN 1979-2824 E-ISSN 2655-8459

Homepage: http://e-journal.stit-islamic-village.ac.id/index.php/istighna

Bahruddin Zaini

Pembelajaran Pendidikan Agama Islam Pada Program Akselerasi

dipacu perkembangan prestasi dan bakatnya. Misalnya SD diselesaikan dalam 4 tahun, SMP dalam 2 tahun begitu juga dengan SMA. ${ }^{4}$

Jaminan pemerintah terhadap pelayanan pendidikan bagi anak berbakat akademik (intelektual) atau lazim disebut peserta didik yang memiliki potensi kecerdasan dan bakat istimewa dinyatakan dalam Undang-undang no. 17/2010 tentang Pengelolaan dan Penyelenggaraan Pendidikan, pasal 134-135 yang berbunyi:

“(1)Pendidikan khusus bagi peserta didik yang memiliki potensi kecerdasan dan/atau bakat istimewa dapat diselenggarakan pada satuan pendidikan formal TK/RA, SD/MI, SMP/MTs, SMA/MA, SMK/MAK, atau bentuk lain yang sederajat.(2) Pendidikan khusus bagi peserta didik yang memiliki potensi kecerdasan dan/atau bakat istimewa bertujuan mengaktualisasikan seluruh potensi keistimewaannya tanpa mengabaikan keseimbangan perkembangan kecerdasan spiritual, intelektual, emosional, sosial, estetik, kinestetik, dan kecerdasan lain. ${ }^{5}$

Program Akselerasi di tingkat pendidikan Dasar rupanya belum populer di Kota Malang. Saat ini baru ada satu SD yang berani menerapkan program akselerasi bagi siswanya. Yaitu SD Laboratorium Universitas Negeri Malang (SD LAB UM). Dimana siswa di sekolah tersebut bisa menyelesaikan pendidikan dasar hanya dengan waktu lima tahun. Sementara normalnya adalah enam tahun.

kelas akselerasi ini dirancang menjadi kelas unggulan, proses rekrutmen untuk melihat potensi siswa dilakukan dengan multidimensional, rekrutmen dilakukan dengan mengembangkan konsep kebrbakatan. konsep itu menyebutkan bahwa anak berbakat mempunyai IQ minimal 125-130 menurut skala wechsler, selain tiu mempunyai task commitment dan creativity qoution di atas rata-rata.

Kelas akselerasi dimulai dikelas 4 yang mempelajari materi pelajaran kelas 4 semester I dan II ditambah dengan materi pelajaran kelas 5 semester I. Pada waktu siswa kelas 5 siswa mempelajari materi pelajaran kelas 5 semester II dan materi pelajaran kelas 6 semester I dan II. Ruang belajar yang baik di sekolah

${ }^{4}$ Ria Kartika, Program Akselerasi; Antara Percepatan, Diskriminan, Dan Pemaksaan .Kompas, Sabtu, 8, Desember 2012. (Http://Www.Google.ComOnline: 06-mei-2015)

${ }^{5}$ Peraturan Pemerintah no. 17/2010 tentang Pengelolaan dan Penyelenggaraan Pendidikan. 
ISTIGHNA, Vol. 3, No 1, Januari 2020 P-ISSN 1979-2824 E-ISSN 2655-8459

Homepage: http://e-journal.stit-islamic-village.ac.id/index.php/istighna

Bahruddin Zaini

Pembelajaran Pendidikan Agama Islam Pada Program Akselerasi

memungkinkan semua peserta didik bergerak leluasa, tidak merasa berdesakan dan saling mengganggu teman yang lain.

Siswa kelas akselerasi di SD Laboratorium Universitas Negeri Malang belum bisa memiliki kesempatan luas untuk belajar mengembangkan aspek Afektif. padatnya materi yang harus mereka terima, banyaknya pekerjaan rumah yang harus mereka selesaikan, ditunjang kemumpuan yang mereka miliki dan teman-teman sekelas yang rata-rata pandai, membuat iklim kerja sama mereka menjadi terbatas. tugas-tugas mereka itu dapat mereka selesaikan sendiri. apalagi siswa yang masih duduk di sekolah mendasar yang seharusnya berada di dunia hiburan dan permainan, mereka di paksa untuk menyelasaikan materi yang begitu padat dengan waktu yang sangat singkat. Peneliti kira perlakuan seperti itu akan berpengaruh tidak baik bagi psikis dan emosional peserta didik kelak. ${ }^{6}$

Menurut Dr. Djma'udin dalam bukunya "Memahami psikologi pendidikan anak SD" beliau berpendapat. ${ }^{7}$

"Pada usia SD, anak-anak mulai intens bersosialisi. Pergaulan dengan kelompok sebaya, akan membuat anak usia SD bisa belajar banyak hal, misalnya setia kawan, bekerja sama, dan bersaing secara sehat. Dengan memahami karakteristik anak-anak usia sekolah dasar di atas, para guru dapat memahami psikologi pendidikan anak, yang pada akhirnya mampu memilih metode pembelajaran yang tepat untuk anak"

${ }^{6}$ Anak yang sering mengalami gangguan emosional akan menyebabkan terbentuknya steroid adrenalin yang berlebihan. Hal ini menyebabkan berkurangnya hormon pertumbuhan pada kelenjar pituitary, akibatnya anak mengalami keterlambatan perkembangan memasuki masa puber. Bagi anak usia SD atau MI, reaksi yang diperlihatkan orang lain terutama oleh teman-teman sebayanya terhadap ukuran dan proporsi tubuhnya mempunyai makna penting.,, Di lihat bukunya... Dr. Triyono dkk, perkembangan peserta didik, Malang: fakultas ilmu pendidikan universitas negeri Malang, 2012, hlm 36

${ }^{7}$ Djama'udin. “Memahami psikologi pendidikan anak SD”.Jakarta: Erlangga, $2001 \mathrm{hlm}$. 32,,, Memahami psikologi pendidikan anak sangat penting dilakukan oleh para orang tua dan guru. Dengan memahami psikologi pendidikan anak secara baik, orang tua dan guru dapat menerapkan metode-metode pendidikan yang sesuai kebutuhan dan tahap perkembangan anak. Dengan demikian, hasil dari proses mendidik pun akan optimal.

Psikologi pendidikan anak berbeda-beda di setiap tahap usia. Psikologi pendidikan anak usia SD tentu saja berbeda dengan psikologi pendidikan anak usia dini ataupun anak-anak pada jenjang pendidikan di atas sekolah dasar. Untuk memahami psikologi pendidikan anak usia sekolah dasar, dapat mulai dengan memahami karaterisktik anak yang duduk di jenjang pendidikan dasar ini. Berikut ini adalah karateristik yang umum dimiliki anak-anak usia SD. (senang bermain, senang bergerak, senang bekerja kelompok, dan senang melakukan secara langsung). anak mengembangkan pemikiran logis, masih sangat terikat pada fakta-fakta perseptual, artinya anak mampu berfikir logis, tetapi masih terbatas pada objek-objek kongkrit, dan mampu melakukan konservasi. 
ISTIGHNA, Vol. 3, No 1, Januari 2020 P-ISSN 1979-2824 E-ISSN 2655-8459

Homepage: http://e-journal.stit-islamic-village.ac.id/index.php/istighna

Bahruddin Zaini

Pembelajaran Pendidikan Agama Islam Pada Program Akselerasi

Untuk itu patut diketahui oleh semua guru SD, khususnya (SD Laboratorium Universitas Negeri Malang) agar kita bisa mengetahui karakteristik dari masing-masing dari pesertadidik kita harus berintegrasi terlebih dahulu dengan mereka, dengan cara mengajak bermain bersama atau selainya. Setelah menegetahui karakteristik dari pesertadidik, maka kita (guru) bisa lebih mudah dalam memberi pengajaran.

Proses pembelajaran Pendidikan Agama Islam khusus bagi anak bekecerdasan tinggi diperlukan pendekatan pembelajaran khusus yaitu menggunakan pendekatan seluruh ranah (sikap, emosi, kognisi dan psikomotor) sehingga muncul pemikiran kreatif. Hal ini sesuai dengan tujuan Pendidikan Agama Islam (PAI) bahwa proses Pendidikan Agama Islam (PAI) yang dilalui dan dialami oleh siswa di sekolah dimulai dari tahapan kognisi, yakni pengetahuan dan pemahaman siswa terhadap ajaran dan nilai-nilai yang terkandung dalam ajaran Islam, untuk selanjutnya menuju ke tahapan afeksi,yakni terjadinya proses internalisasi ajaran dan nilai agama ke dalam dirisiswa, dalam arti menghayati dan meyakininya. Tahapan afeksi ini terkait dengan kognisi, dalam arti penghayatan dan keyakinan siswa menjadi kokoh jika dilandasi oleh pengetahuan dan pemahamannya terhadap ajaran dan nilai agama Islam. Melalui tahapan afeksi tersebut diharapkan diharapkan dapat tumbuh motivasi dalam diri siswa dan tergerak untuk mengamalkan dan menaati ajaran Islam (tahapan psikomotorik) yang telah diinternalisasi dalam dirinya. Dan statemen ini selaras dengan tujuan mata pelajaran PAI di Sekolah Dasar

Oleh karena itu, menjadi penting Pendidikan Agama Islam bagi anak yang memiliki kecerdasan dan keberbakatan tingkat tinggi ini, Dalam hal ini Pendidikan Agama Islam bagi anak berbakat memiliki kontribusi besar, agar anak itu mampu menjadi siswa akseleran yang berkualitas, memiliki kecerdasan intelektual, emosional, dan spiritual yang berimbang. Sehingga dapat direalisasikan dalam kehidupan sehari-hari dengan bentuk sikap berbudi pekerti luhur dan bermartabat serta beriman dan bertaqwa kepada Tuhan Yang Maha Esa.

\section{B. HASIL DAN PEMBAHASAN}


ISTIGHNA, Vol. 3, No 1, Januari 2020 P-ISSN 1979-2824 E-ISSN 2655-8459

Homepage: http://e-journal.stit-islamic-village.ac.id/index.php/istighna

Bahruddin Zaini

Pembelajaran Pendidikan Agama Islam Pada Program Akselerasi

\section{Pengertian Pendidikan Agama Islam}

Pendidikan agama Islam mempunyai kedudukan dan peranan yang sangat penting di dalam pembangunan nasional, ${ }^{8}$ Menurut Zakiyah Daradjat pendidikan agama Islam adalah suatu usaha untuk membina dan mengasuh peserta didik agar senantiasa dapat memahami ajaran Islam secara menyeluruh. Lalu menghayati tujuan, yang pada akhirnya dapat mengamalkan serta menjadikan Islam sebagai pandangan hidup dan rahmatan lil a 'lamin bukan lil muslimin. ${ }^{9}$

Selain itu Direktorat Jenderal Pembina Kelembagaan Agama Islam menjelaskan bahwa:

Pendidikan agama Islam ialah, segala usaha yang berupa pengajaran bimbingan terhadap anak agar kelak setelah selesai pendidikannya dapat memahami, menghayati dan mengamalkan ajaran agamanya serta menjadikannya sebagai way of life (jalan kehidupan) sehari-hari baik dalam kehidupan pribadi maupun sosial kemasyarakatan. ${ }^{10}$

Sedangkan definisi pendidikan agama Islam disebutkan dalam Kurikulum 2004 Standar Kompetensi Mata Pelajaran Pendidikan Agama Islam SD dan MI adalah :

"Pendidikan agama Islam adalah upaya sadar dan terencana dalam menyiapkan peserta didik untuk mengenal, memahami, menghayati, mengimani, bertakwa, berakhlak mulia, mengamalkan ajaran agama Islam dari sumber utamanya kitab suci Al-Quran dan Hadits, melalui kegiatan bimbingan, pengajaran, latihan, serta penggunaan pengalaman."

Jadi dengan adanya beberapa rumusan pengertian diatas, maka jelaslah bahwa yang dimaksud dengan pendidikan agama Islam itu ialah usaha sadar generasi tua (pendidik) untuk mengarahkan pengalaman, pengetahuan, kecakapan dan ketrampilan kepada generasi muda (anak didik) agar kelak

\footnotetext{
Hlm, 1

${ }^{8}$ Drs, H, Abu Ahmadi, Dasar-Dasar Pendidikan Agama Islam,, (Jakarta: Bumi Aksara,2004)

9 Abd. Majid Dan Dian Andayani, Pendidikan Agama Islam Berbasis Kompetensi:Konsep Dan Imlementasi Kurikulum (Bandung: PT Rosdakarya, 2004), Hlm. 130

${ }^{10}$ Departemen Agama RI, Pedoman Pelaksanaan Pendidikan Agama Islam, Pada SMTA. (Jakarta: Bimbaga Islam pada Sekolah Umum, 1985/1986),Hlm. 9
} 
ISTIGHNA, Vol. 3, No 1, Januari 2020 P-ISSN 1979-2824 E-ISSN 2655-8459

Homepage: http://e-journal.stit-islamic-village.ac.id/index.php/istighna

Bahruddin Zaini

Pembelajaran Pendidikan Agama Islam Pada Program Akselerasi

menjadi manusia muslim, bertaqwa kepada Allah SWT, berbudi luhur, kepribadian yang utuh yang secara langsung memahami, menghayati dan mengamalkan ajaran agama Islam dalam kehidupan sehari-hari.

\section{Tujuan Pendidikan Agama Islam}

Tujuan Pendidikan Agama Islam ialah pembentukan kepribadian yang seluruh aspeknya dijiwai oleh ajaran Islam. Orang yang berkepribadian muslim dalam Al-Qur'an disebut “Muttaqien”. Untuk mencapai tujuan Pendidikan Agama Islam ini, membutuhkan suatu program pembelajaran yang formal yang mempunyai tujuan yang jelas dan konkret.

Kemudian pemerintah menyelenggarakan suatu sistem pendidikan nasional yang tercantum dalam Undang-Undang dasar No. 20 Tahun 2003

"Untuk mencapai kwalitas yang disebutkan oleh Al-Qur'an dan hadits sedangkan fungsi pendidikan nasional adalah mengembangkan kemampuan dan membentuk watak serta peradaban bangsa yang bermartabat dalam rangka mencerdaskan kehidupan bangsa, bertujuan untuk mengembangkan potensi peserta didik agar menjadi manusia yang beriman dan bertakwa kepada Tuhan Yang Maha Esa, berakhlak mulia, sehat, berilmu, cakap, kreatif, mandiri, berbudi pekerti, ${ }^{11}$ Ahlakul karimah, dan menjadi warga negara yang demokratis serta bertanggung jawab. ${ }^{12}$

Adapun yang perlu dijadikan kajian ini adalah masalah tahapan proses mewujudkan tujuan tersebut, seiring dengan perubahan yang terjadi dalam masyarakat. Muhaimin mengemukakan guna mewujudkan hal tersebut proses pendidikan agama Islam yang dilalui dan dialami oleh siswa di sekolah hendaknya dimulai dari tahapan kognisi, yakni pengetahuan dan pemahaman siswa terhadap ajaran dan nilai-nilai yang terkandung dalam ajaran Islam.

${ }^{11}$ Pendidikan budi pekerti atau akhlak dalamajaran Islam merupakan salah satu pokok penting yang harus diajarkan, supaya umatnya mempunyai akhlak yang mulia dan dapat melaksanakannya dalam kehidupan sehari-hari. Sebagaimana yang telah dicontohkan oleh Nabi Muhammad S.A.W. Bahkan tugas utama Rasulullah SAW diutus ke dunia ini dalam rangka menyempurnakan akhlak sebagaimana sabda-Nya:

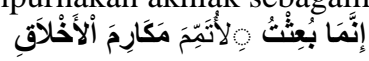

Artinya:"sesungguhnya aku diutus di muka bumi ini tidak lain untuk menyempurnakan akhlak. "Dari rumusan tujuan PAI tersebut di atas dapat diambil pengertian bahwa pada dasarnya ada titik penekanan yang amat esensial dalam PAI. Titik penekanan tersebut lebih merupakan sebuah rangkaian filosofis di Mana harapan dari proses pembelajaran PAI adalah Manusia beriman dah berakhlak.

${ }^{12}$ Undang-Undang dasar No. 20 Tahun 2003 
ISTIGHNA, Vol. 3, No 1, Januari 2020 P-ISSN 1979-2824 E-ISSN 2655-8459

Homepage: http://e-journal.stit-islamic-village.ac.id/index.php/istighna

Bahruddin Zaini

Pembelajaran Pendidikan Agama Islam Pada Program Akselerasi

Selanjutnya setelah siswa mampu memahami, maka dilanjutkan kepada tahapan afeksi, yakni proses internalisasi ajaran dan nilai agama ke dalam diri siswa, dalam arti menghayati dan meyakininya. Dari tahapan afeksi diharapkan dapat tumbuh dalam diri siswa motivasi untuk mengamalkan dan merealisasikan materi-materi PAI (psikomotor).

Pencapaian tujuan pembelajaran PAI sangat tergantung pada tekad, semangat dan erja keras para Guru PAI. Karena hanya dengan tekad, semangat dan kerja keras akan dapat menunjang serta mendorong tercapainya hasil yang baik. Tentunya didasari oleh kemampuan-kemampuan dasar (basic abilities) sebagai pekerja professional. Dengan kata lain Guru PAI yang memiliki kompetensi personal, professional, dan sosial yang terakumulasi dalam kompetensi religius yang hanif. Sehingga secara terpadu mampu mewujudkan tujuan pembelajaran PAI sebagaimana diuraikan di atas.

Dapat dikemukakan bahwa keberhasilan pembelajaran PAI sangat ditentukan oleh pemikir, perencana, dan pelaksana PAI, yaitu Guru PAI, dengan harapan dapat memacu wawasan untuk menciptakan dan memberdayakan potensi generasi muda Islam (siswa) agar lebih kreatif, inovatif, dan produktif, guna memasuki dunia yang penuh persaingan dengan keadaan unggul dan diperhitungkan. ${ }^{13}$

\section{Ruang Lingkup pendidikan Agama Islam}

Sebagaimana diketahui, bahwa inti ajaran Islam meliputi: (a) masalah keimanan; (b) masalah keIslaman (syari'ah); dan (c) masalah ikhsan (akhlak). Yang kemudian dilengkapi dengan pembahasan dasar hukum Islam yaitu AlQur'an dan Al-Hadits, serta ditambah dengan sejarah Islam (tarikh), sehingga secara berurutan: (a) ilmu tauhid/keimanan; (b) ilmu fiqih; (c) Al-Qur'an; (d) Al-Hadits; (e) akhlak; dan (f) tarikh Islam.

Menurut Abdul Majid dan Dian Andayani mata pelajaran Pendidikan Agama Islam itu secara keseluruhannya meliputi lingkup: Al-Qur'an dan alhadis, keimanan, akhlak, fiqih / ibadah, dan sejarah, sekaligus menggambarkan

${ }^{13}$ Muhaimin, op.cit., hlm. 79 
ISTIGHNA, Vol. 3, No 1, Januari 2020 P-ISSN 1979-2824 E-ISSN 2655-8459

Homepage: http://e-journal.stit-islamic-village.ac.id/index.php/istighna

Bahruddin Zaini Pembelajaran Pendidikan Agama Islam Pada Program Akselerasi

bahwa ruang lingkup pendidikan agama Islam mencakup perwujudan keserasian, keselarasan, dan keseimbangan hubungan manusia dengan Allah SWT, diri sendiri, sesama manusia, makhluk lainnya maupun lingkungannya. ${ }^{14}$ Tiap jenis kurikulum mempunyai ciri/karakteristik termasuk pendidikan agama Islam. Abdurrahman An-Nahlawi menjelaskan bahwa kurikulum islami harus memenuhi beberapa ketentuan, yaitu:

a. Memiliki sistem pengajaran dan materi yang selaras dengan fitrah manusia serta bertujuan untuk menyucikan manusia, memelihara dari penyimpangan, dan menjaga keselamatan fitrah manusia.

b. Harus mewujudkan tujuan pendidikan Islam.

c. Harus sesuai dengan tingkatan pendidikan baik dalam hal karakteristik, tingkat pemahaman, jenis kelamin, serta tugas-tugas kemasyarakatan yang telah dirancang dalam kurikulum.

d. Memperhatikan tujuan-tujuan masyarakat yang realistis, menyangkut penghidupan dan bertitik tolak dari keislaman yang ideal, seperti merasa bangga menjadi umat Islam.

e. Tidak bertentangan dengan konsep-konsep Islam.

f. Harus realistis sehingga dapat diterapkan selaras dengan kesanggupan Negara yang hendak menerapkannya sehingga sesuai dengan tuntutan dan kondisi Negara itu sendiri.

g. Harus memilih metode yang relastis sehingga dapat diadaptasikan ke dalam berbagai kondisi, lingkungan dan keadaan tempat ketika kurikulum itu harus ditetapkan.

h. Harus efektif, dapat memberikan hasil pendidikan behavioristik.

i. Memperhatikan aspek pendidikan tentang segi-segi perilaku yang bersifat aktivitas langsung seperti berjihad, dakwah Islam, serta pembangunan masyarakat muslim dalam lingkungan persekolahan sehingga kegiatan ini dapat mewujudkan seluruh rukun Islam dan syiarnya. $^{15}$

\footnotetext{
${ }^{14}$ Abdul Majid, op.cit.,hlm. 131

${ }^{15}$ Abdul Majid dan Dian Andayani, op.cit., hlm. 79-80
} 
ISTIGHNA, Vol. 3, No 1, Januari 2020 P-ISSN 1979-2824 E-ISSN 2655-8459

Homepage: http://e-journal.stit-islamic-village.ac.id/index.php/istighna

Bahruddin Zaini

Pembelajaran Pendidikan Agama Islam Pada Program Akselerasi

Agar kemampuan-kemampuan lulusan atau out put yang diharapkan bisa tercapai, maka tugas Guru pendidikan agama Islam adalah berusaha secara sadar untuk membimbing, mengajar, dan melatih siswa sebagai siswa agar dapat: (a) Meningkatkan keimanan dan ketaqwaan kepada Allah SWT yang telah ditanamkan dalam lingkungan keluarga; (b) Menyalurkan bakat dan minatnya dalam mendalami bidang agama serta mengembangkannya secara optimal, sehingga dapat dimanfaatkan untuk dirinya sendiri dan dapat pula bermanfaat bagi orang lain; (c) Memperbaiki kesalahan-kesalahan, kekurangan-kekurangan dan kelemahan-kelemahannya dalam keyakinan, pemahaman dan pengamalan ajaran Islam dalam kehidupan sehari-hari; (d) Menangkal dan mencegah pengaruh negatif dari kepercayaan, paham atau budaya lain yang membahayakan dan menghambat perkembangan keyakinan siswa; (e) Menyesuaikan diri dengan lingkungannya, baik lingkungan fisik maupun lingkungan sosial yang sesuai dengan ajaran Islam; (f) Menjadikan ajaran Islam sebagai pedoman hidup untuk mencapai kebahagiaan hidup di dunia dan akhirat; dan (g) Mampu memahami, mengilmui pengetahuan agama Islam secara menyeluruh sesuai dengan daya serap siswa dan keterbatasan waktu yang tersedia. ${ }^{16}$ Sedangkan dalam Permendiknas RI NO.22 Tahun 2006 ruang lingkup Pendidikan Agama Islam tingkat sekolah Dasar meliputi, AlQuran, Al-Hadist, Aqidah, Figih, dan tarikh (sejarah Islam) ${ }^{17}$

\section{Pengertian Program Akselerasi}

Anak berbakat merupakan aset pembangunan nasional yang luar biasa, untuk itu di perlukan kesadaran akan akan pentingnya menbina dan mengembangkan anak yang memiliki kemampuan dan kecerdasan luar biasa secara optimal melalui pelayanan pendidikan. Sebaliknya apabila mendapat pendidikan yang tidak sesuai dengan bakat, minat, kemapuan dan kecerdasan maka tidak mustahil mereka akan berprestasi di bawah potensinya (under

\footnotetext{
${ }^{16}$ Muhaimin, op.cit., hlm. 53

${ }^{17}$ Departemen Pendidikan Nasional, Standar Kompetensi Dan Kompetensi Dasar Tingkat SDMata pelajaran Agama Islam, (Direktorat Jenderal Mandikdasmen 2007) hal. 2
} 
ISTIGHNA, Vol. 3, No 1, Januari 2020 P-ISSN 1979-2824 E-ISSN 2655-8459

Homepage: http://e-journal.stit-islamic-village.ac.id/index.php/istighna

Bahruddin Zaini

Pembelajaran Pendidikan Agama Islam Pada Program Akselerasi

achiever) atau bahkan menjadi anak yang bermasalah (mengalami gangguan belajar $)^{18}$

Sebagai model pelayanan, akselerasi dapat diartikan sebagai model layanan pembelajaran dengan cara lompat kelas, misalnya bagi siswa yang memiliki kemampuan tinggi diberi kesempatan untuk mengikuti pelajaran pada kelas yang lebih tinggi. Sementara itu, model kurikulum, akselerasi berarti mempercepat bahan ajar dari yang seharusnya dikuasai oleh siswa saat itu sehingga siswa dapat menyelesaikan program studinya lebih awal. Hal ini dapat dilakukan dengan cara menganalisis materi pelajaran dengan materi yang esensial dan kurang esensial. ${ }^{19}$

Menurut Sutratinah Tirtonegoro percepatan (acceleration) adalah cara penanganan anak super normal dengan memperbolehkan naik kelas secara meloncat atau menyelesaikan program reguler di dalam jangka waktu yang lebih singkat ${ }^{20}$. Hal senada juga disampaikan oleh Ulya Latifah Lubis (dalam Hawadi) yang mendefinisikan istilah akselerasi sebagai program pelayanan yang diberikan kepada siswa dengan tingkat keberbakatan tinggi agar dapat menyelesaikan masa belajarnya lebih cepat dari siswa yang lain (program reguler). ${ }^{21}$

Siswa yang seharusnya menyelesaikan studi SMP (Sekolah Menengah Pertama) atau SMA (Sekolah Menengah Atas)nya dalam waktu 3 tahun dapat menyelesaikan materi kurikulum (yang telah didiversifikasi) dalam waktu 2 tahun saja. Berdasarkan pengertian di atas, dapat dipahami bahwa akselerasi adalah program layanan belajar yang diperutukkan bagi mereka yang memiliki kemampuan tinggi supaya dapat menyelesaikan studinya sesuai kecepatan dan kemampuannya.

\footnotetext{
${ }^{18}$ Rudi Purwanto, Penerapan Program Akselerasi Di SMPN 3 Tanggerang Selatan, Skripsi, Perpustakaan UIN Syarif Hidayatullah Jakarta, (Jakarta, 2010 H/1431), Hlm, 12

${ }^{19}$ Reni Akbar-Hawadi, Akselerasi: A-Z Inforamasi Program Percepatan Belajar. (Jakarta: Grasindo Widiasarana Indonesia, 2004), Hlm. 5-6

${ }^{20}$ Sutratinah Tirtonegoro, Anak Supernormal Dan Prgram Pendidikannya (Yotyakarta: Bumi Aksara, 2001), Hlm. 104

${ }^{21}$ Reni Akbar-Hawadi , Op.Cit., Hlm.121
} 
ISTIGHNA, Vol. 3, No 1, Januari 2020 P-ISSN 1979-2824 E-ISSN 2655-8459

Homepage: http://e-journal.stit-islamic-village.ac.id/index.php/istighna

Bahruddin Zaini

Pembelajaran Pendidikan Agama Islam Pada Program Akselerasi

Program ini secara umum memenuhi kebutuhan peserta didik yang memiliki karakteristik spesifik dari segi perkembangan kognitif dan afektif. Secara khusus memberi pelayanan kepada siswa berbakat untuk dapat menyelesaikan pendidikan lebih cepat dari biasanya. ${ }^{22}$

\section{Kurikulum Program Akselerasi}

Kurikulum merupakan seperangkat rencana dan pengaturan mengenai isi dan bahan pelajaran serta cara yang digunakan sebagai pedoman penyeleggaraa kegiatan belajar-mengajar. ${ }^{23}$ Serta kurikulum bukan hanya sebagai pedoman tapi juga meliputi semua kegiatan yang direncakan, melainkan juga peristiwa-peristiwa yang terjadi di bawah pangawasan sekolah, ${ }^{24}$ Sedangkan mururut (Oemar Hamalik) merupakan program pendidikan yang disediakan oleh lembaga pendidikan (sekolah) bagi siswa, dan pengertian kurikulum mencakup empat pertanyaan yang mendasar yang harus dijawab dalam mengembangkan kurikulum dan rencana pengajaran yaitu (a) apa tujuan yang harus dicapai oleh sekolah, (b) pengalaman-pengalaman belajar seperti apa yang dapat dilaksanakan guna mencapai tujuan yang dimaksud, (c) bagaimana pengalaman tersebut diorganisasikan secara efektif, dan (d) bagaimana cara menentukan bahwa tujuan pendidikan telah tercapai. ${ }^{25}$ Dari pernyataan di atas dapat disimpulkan kurikulum memiliki empat unsur, yaitu:

a. tujuan yang ingin dicapai,

b. struktur dan isi kurikulum yang berupa mata pelajaran

c. pengorganisasian kegiatan belajar-mengajar, dan

d. penilaian utuk mengetahui apakah tujuan telah tercapai atau belum.

Muatan materi kurikulum untuk program akselerasi tidak berbeda dengan kurikulum standar yang digunakan untuk program regular.

\footnotetext{
${ }^{22}$ Reni Akbar-Hawadi, Loc. Cit.

${ }^{23}$ Prof. Drs.H. Dakir, Perencanaan Dan Pengembangan Kurikulum, (Jakarta,Renika Cipta,2010)) Hlm, 1-2

${ }^{24}$ Prof, Dr, Nasution, Kurikulim Dan Pengajaran (Bandung, PT Bumi Aksara 1989), Hlm 5

${ }^{25}$ Oemar hamalik, manajemen pengembangan kurikulum, (bandung,PT remaja rosda
} karya 2006), hlm, 10 
ISTIGHNA, Vol. 3, No 1, Januari 2020 P-ISSN 1979-2824 E-ISSN 2655-8459

Homepage: http://e-journal.stit-islamic-village.ac.id/index.php/istighna

Bahruddin Zaini

Pembelajaran Pendidikan Agama Islam Pada Program Akselerasi

Perbedaannya terletak pada penyusunan kembali struktur program pengajaran dalam alokasi waktu yang lebih singkat. Program akselerasi ini akan menjadikan kurikulum standar yang biasanya ditempuh siswa SMA dalam tiga tahun menjadi hanya dua tahun. Pada tahun pertama, siswa akan mempelajari seluruh materi kelas 1 ditambah dengan setengah materi kelas 2. Di tahun kedua, mereka akan mempelajari materi kelas 2 yang tersisa dan seluruh materi kelas $3 .^{26}$

Pengaturan kembali program pembelajaran pada kurikulum standar yang biasanya diberikan dengan alokasi waktu sembilan cawu menjadi enam cawu dilakukan tanpa mengurangi isi kurikulum. Kuncinya terletak pada analisis materi kurikulum dengan kalender akademis yang dibuat khusus. Seperti diketahui, untuk siswa berbakat intelektual dengan keberbakatan tinggi, tidak semua materi kurikulum standar perlu disampaikan dalam bentuk tatap muka dan atau dengan irama belajar yang sama dengan siswa regular.

Oleh karena itu, setiap guru yang mengajar di kelas akselerasi perlu terlebih dahulu melakukan analisis materi pelajaran untuk menentukan sifat materi yang esensial dan kurang. Suatu materi dikatakan memiliki konsep esensial bila memenuhi kriteria berikut ini: (1) konsep dasar; (2) konsep yang menjadi dasar untuk konsep berikut; (3) konsep yang berguna untuk aplikasi; (4) konsep yang sering muncul pada EBTANAS; (5) konsep yang sering muncul pada UMPTN untuk SMA. Materi pelajaran yang diidentifikasi sebagai konsep-konsep yang esensial diprioritaskan untuk diberikan secara tatap muka, sedangkan materi-materi yang non-esensial, kegiatan pembelajarannya dapat dilakukan dalam bentuk kegiatan mandiri 27

Dijelaskan juga oleh Conny R Semiawan, sesuai dengan karakter anak yang berkemampuan kecerdasan di atas rata-rata ini, kurikulum atau GBPP atau materi pelajaran telah didiskusikan dan disusun oleh pusat pengembangan kurikulum sejak 1981. Sebelum uji coba pelaksanaan Program Anak Berbakat

\footnotetext{
${ }^{26}$ Reni Akbar-Hawadi Dkk, Kurikulum Berdiferensiasi, ( Jakarta: Grasindo Widiasarana Indonesia, 2001), Hlm.3

${ }^{27}$ Ibid., hlm. 124
} 
ISTIGHNA, Vol. 3, No 1, Januari 2020 P-ISSN 1979-2824 E-ISSN 2655-8459

Homepage: http://e-journal.stit-islamic-village.ac.id/index.php/istighna

Bahruddin Zaini

Pembelajaran Pendidikan Agama Islam Pada Program Akselerasi

dilaksanakan tahun 1984 kurikulum berdeferensiasi dibuat. Dikaitkan dengan hal di atas kemampuan gurulah yang selalu harus ditingkatkan, misalnya kecekatan dalam hal menganalisis kurikulum sesuai perkembangan anak dan kebutuhan penanjakan kemampuan fikir atau mental anak dan membuat anak senang belajar. ${ }^{28}$

Kurikulum yang digunakan pada program akselerasi adalah kurikulum Nasional dan muatan lokal, yang dimodifikasi dengan penekanan pada materi yang esensi dan dikembangkan melalui sistem pembelajaran yang dapat memacu dan mewadahi integrasi pengembangan spiritual, logika, etika, dan estetika serta mengembangkan kemampuan berfikir holistik, kreatif, sistemik, linier, dan konvergen utuk memenuhi tuntutan masa kini dan masa depan. ${ }^{29}$ Dengan demikian kurikulum program akselerasi adalah kurikulum yang diberlakukan untuk satuan pendidikan yang bersangkutan, sehingga lulusan program akselerasi memiliki kualitas dan standar kompetensi yang sama dengan lulusan program reguler. Perbedaannya hanya terletak pada waktu keseluruhan yang ditempuh dalam menyelesaikan pendidikannya lebih cepat bila dibanding dengan program reguler.

Kurikulum akselerasi ini dikembangkan secara diferensiatif. Artinya kurikulum yang digunakan disesuaikan dengan kemampuan yang dimiliki oleh siswa. Diferensiasi dalam kurikulum akselerasi menurut Cledening \& Davies, 1983 (dalam Hawadi Dkk) adalah isi pelajaran yang menunjuk pada konsep dan proses kognitif tingkat tinggi, strategi intruksional yang akomodatif dengan gaya belajar anak berbakat dan rencana yang memfasilitasi kinerja siswa. ${ }^{30}$

\section{Implementasi dan Kendala Pembelajaran Pendidikan Agama Islam (PAI) Pada Program Akselerasi}

\section{a. Aplikasi Kurikulum Program Akselerasi (berdiferensiasi).}

\footnotetext{
${ }^{28}$ Conny R Semiawan dan Djeniah Alim, Petunjuk Layanan Dan Pembinaan Kecerdasan Anak (Bandung: PT Remaja Rosdakarya, 2002), hlm. 69

${ }^{29}$ Direktorat, op.cit., hlm. 39

${ }^{30}$ Reni Akbar-Hawadi Dkk, Kurikulum Berdiferensiasi, ( Jakarta: Grasindo Widiasarana Indonesia, 2001), hlm.3
} 
ISTIGHNA, Vol. 3, No 1, Januari 2020 P-ISSN 1979-2824 E-ISSN 2655-8459

Homepage: http://e-journal.stit-islamic-village.ac.id/index.php/istighna

Bahruddin Zaini

Pembelajaran Pendidikan Agama Islam Pada Program Akselerasi

Kurikulum berdiferensiasi yang dikembangkan untuk memenuhi kebutuhan pendidikan peserta didik yang memiliki potensi kecerdasan dan bakat istimewa dengan cara memberikan pengalaman belajar yang berbeda dalam arti kedalaman, keluasan, percepatan, maupun dalam jenisnya. ${ }^{31}$

Dalam kenyataannya, mendiferensiasikan kurikulum berarti mengubah konten proses, produk, dan situasi (lingkungan belajar). Hal ini bisa dilaksanakan pada setiap jenjang pendidikan dengan memperhatikan faktor kematangan intelektual, latar belakang, dan kesiapan belajar serta interes siswa.

Bruner dalam kaitan dengan ini menyatakan, hendaklah beranjak dari hipotesis bahwa mata pelajaran apa pun bisa diajarkan secara efektif dengan cara yang jujur pada setiap anak dalam kondisi perkembangan kapan pun. Sebagai contoh kita ambil Pendidikan Agama Islam. ${ }^{32}$

Dikuatkan juga oleh Sutratinah Tirtonegoro, bahwa untuk melayani pendidikan Anak Supernormal maka perencanaan kurikulum harus mengalami perubahan-perubahan antara lain:

a. Memperkaya kurikulum dengan menambah mata pelajaran.

b. Memberi kesempatan memperkembangkan sosial, emosi, dan kebudayaan.

c. Dengan mengadakan Sekolah Khusus, Kelas Khusus, dan Fasilitasfasilitas khusus.

d. Untuk SLTA lebih diperluas dan diperdalam.

e. memberi kesempatan seluas-luasnya untuk memperoleh pengalaman lebih banyak untuk perkembangan bakatnya. ${ }^{33}$

\section{b. Pendidikan Agama Islam Bagi Anak Berbakat.}

Sejalan dengan rumusan yang terkandung dalam kurikulum yang berdiferensiasi untuk anak berbakat tinggi, seyogianyalah Pendidikan Agama Islam (PAI) ditanamkan dalam pribadi anak sejak ia lahir bahkan sejak dalam

\footnotetext{
${ }^{31}$ Pedoman, op.cit., hlm. 41-42

${ }^{32}$ Conny Semiawan, Perspektif Pendidikan Anak Berbakat (Jakarta: PT Gramedia Widiasarana, 1997), hlm. 141

${ }^{33}$ Sutratinah, op.cit., hlm. 120
} 
ISTIGHNA, Vol. 3, No 1, Januari 2020 P-ISSN 1979-2824 E-ISSN 2655-8459

Homepage: http://e-journal.stit-islamic-village.ac.id/index.php/istighna

Bahruddin Zaini

Pembelajaran Pendidikan Agama Islam Pada Program Akselerasi

kandungan dan kemudian hendaklah dilanjutkan pembinaan pendidikan ini di sekolah, mulai dari taman kanak-kanak sampai dengan perguruan tinggi.

Dalam mewujudkan Tujuan Pendidikan Nasional, Pendidikan Agama Islam di sekolah memegang peranan yang sangat penting. Oleh karena itu Pendidikan Agama Islam di Indonesia dimasukkan ke dalam kurikulum nasional yang wajib diikuti oleh semua anak didik mulai dari SD sampai dengan Perguruan Tinggi. ${ }^{34}$

Sangat mengecewakan bila kita memiliki anak yang pandai, apalagi prestasi akademiknya cemerlang dan masuk kelas akseleran, bila suatu saat nanti mereka terjebak oleh rasionalitasnya dan tak dapat memaknai dan menikmati hidupnya sendiri. Sangat menyedihkan ketika kita melihat realitas masyarakat yang dikuasai oleh kemiskinan spiritual yang mengakibatkan penderitaan dan kehancuran bidang-bidang kehidupan bangsa kita. ${ }^{35}$

Untuk itulah, mereka membutuhkan Pendidikan Agama Islam untuk mencapai keseimbangan pertumbuhan diri pribadi manusia muslim secara menyeluruh melalui latihan kejiwaan, akal fikiran, kecerdasan, perasaan, dan pancaindera sehingga memiliki kepribadian yang utama. Oleh karena itu, pendidik Islam harus mengembangkan seluruh aspek kehidupan manusia baik spiritual, intelektual, imajinasi (fantasi), jasmani, keilmiahan, bahasa, serta mendorong aspek-aspek itu kearah kebaikan atau kesempurnaan hidup. ${ }^{36}$

Dengan uraian singkat, dapat difahami bahwa tujuan pendidikan Islam adalah meningkatkan taraf kehidupan manusia melalui seluruh aspek yang ada sehingga sampai kepada tujuan yang telah ditetapkan dengan proses tahap demi tahap. Manusia akan dapat mencapai kematangan Dalam hidupnya.. ${ }^{37}$

Dalam proses pembelajaran pendidikan agama terdapat tiga komponen utama yang saling berpengaruh. Ketiga komponen tersebut adalah: (1) kondisi pembelajaran; (2) metode pembelajaran; (3) hasil pembelajaran.

\footnotetext{
${ }^{34}$ Abdul Madjid dan Dian Andayani, op,cit., hlm.139-140.

${ }^{35}$ Reni Akbar-Hawadi (Ed), op.cit., hlm. 203.

${ }^{36}$ Zuhairini, op.cit., hlm. 8.

${ }^{37}$ Zuhairini, loc.cit.
} 
ISTIGHNA, Vol. 3, No 1, Januari 2020 P-ISSN 1979-2824 E-ISSN 2655-8459

Homepage: http://e-journal.stit-islamic-village.ac.id/index.php/istighna

Bahruddin Zaini Pembelajaran Pendidikan Agama Islam Pada Program Akselerasi

Selanjutnya klasifikasi dan hubungan antar komponen yang mempengaruhi pembelajaran PAI tersebut dapat digambarkan dalam bagan berikut:

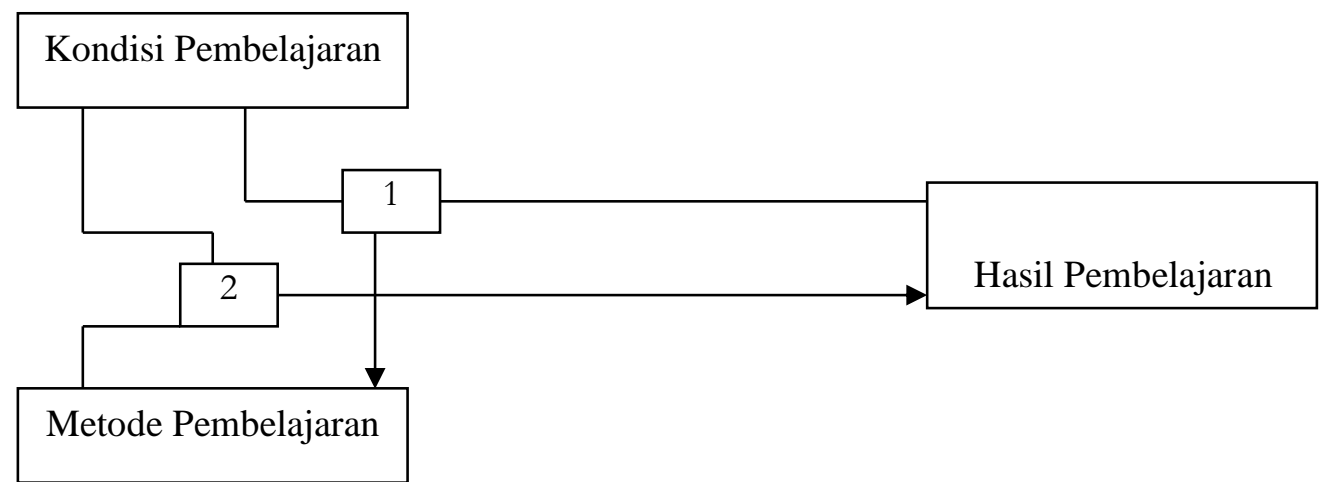

Gambar: Interelasi Variabel Pembelajaran (Degeng, 1989) ${ }^{38}$

Dari diagram di atas, dapat diuraikan lebih rinci mengenai ketiga komponen utama faktor-faktor yang mempengaruhi pembelajaran PAI tersebut, yakni sebagai berikut:

1) Kondisi pembelajaran Pendidikan Agama Islam

Kondisi pembelajaran PAI adalah semua faktor yang mempengaruhi penggunaan metode pembelajaran PAI. Karena itu, perhatian kita adalah berusaha mengindetifikasi dan mendeskripsikan faktor-faktor yang termasuk kondisi pembelajaran, yaitu (1) tujuan dan karakteristik bidang studi PAI; (2) kendala dan karakteristik bidang studi PAI, dan (3) karakteristik peserta didik. ${ }^{39}$

Tujuan pembelajaran PAI adalah pernyataan tentang hasil pembelajaran PAI. Tujuan pembelajaran ini bersifat umum, bias dalam kontinum umum-khusus, dan bias bersifat khusus. Tujuan PAI yang bersifat umum tercermin dalam GBPP mata pelajaran PAI di sekolah, bahwa PAI bertujuan "meningkatkan keimanan, pemahaman, penghayatan, dan pengamalan siswa terhadap agama Islam sehingga menjadi manusia muslim yang beriman dan bertaqwa kepada Allah

\footnotetext{
${ }^{38}$ Muhaimin, op.cit., hlm. 146

${ }^{39}$ Ibid., hlm. 150
} 
ISTIGHNA, Vol. 3, No 1, Januari 2020 P-ISSN 1979-2824 E-ISSN 2655-8459

Homepage: http://e-journal.stit-islamic-village.ac.id/index.php/istighna

Bahruddin Zaini Pembelajaran Pendidikan Agama Islam Pada Program Akselerasi

SWT serta berakhlak mulia dalam kehidupan pribadi, bermasyarakat, berbangsa, dan bernegara serta untuk melanjutkan pendidikan pada jenjang yang lebih tinggi"40

Pernyataan tujuan tersebut masih sangat luas, idealis, dan sangat umum. Sehingga perlu dijabarkan unsur-unsur yang terkandung dalam rumusan tujuan tersebut pada tataran yang lebih rinci dan operasional. Tujuan dalam kontinum umum-khusus, misalnya siswa memiliki kesadaran dan tanggung jawab terhadap lingkungan serta terbiasa menampilkan perilaku agama dalam kehidupan sehari-hari. Tujuan tersebut masih perlu dijabarkan yang lebih khusus lagi, misalnya: (1) siswa dapat memiliki lingkungan yang bersih, sehat, indah, agamis, dan; (3) siswa dapat berperilaku menjaga lingkungan yang sehat, bersih, indah, dan agamis dalam kehidupan sehari-hari.

Karakteristik bidang studi PAI adalah aspek-aspek suatu bidang studi PAI yang terbangun dalam struktur isi dan konstruk atau tipe isi bidang studi. Aspek tersebut berupa fakta, konsep, dalil atau hukum, prinsip atau akidah, prosedur dan keimanan yang menjadi landasan dalam mendeskripsikan strategi pembelajaran. ${ }^{41}$

Karakteristik siswa adalah kualitas perseorangan siswa, seperti bakat, kemampuan awal yang dimiliki, motivasi belajar, dan kemungkinan hasil belajar yang akan dicapai. Karakteristik siswa akan mempengaruhi strategi pengelolaan pembelajaran. Namun perlu diingat, pada tingkat tertentu, dimungkinkan suatu kondisi pembelajaran akan mempengaruhi setiap komponen pemilihan metode pembelajaran. Seperti karakteristik siswa dapat mempengaruhi pemilihan strategi pengorganisasian isi dan strategi penyampaian pembelajaran PAI. ${ }^{42}$

2) Metode Pembelajaran

\footnotetext{
${ }^{40}$ Garis-garis, op.cit.

${ }^{41}$ Muhaimin, loc.cit.

${ }^{42}$ Ibid., hlm. 151
} 
ISTIGHNA, Vol. 3, No 1, Januari 2020 P-ISSN 1979-2824 E-ISSN 2655-8459

Homepage: http://e-journal.stit-islamic-village.ac.id/index.php/istighna

Bahruddin Zaini

Pembelajaran Pendidikan Agama Islam Pada Program Akselerasi

Metode pembelajaran dapat diklasifikasikan dari pendapat Reigeluth yang sepadan dengan possibilities for action dari Simon, atau dengan komponen proses pembelajaran dari Glaser. Selanjutnya variabel metode pembelajaran tersebut diklasifikasikan lebih lanjut menjadi 3 jenis, yaitu: (1) strategi pengorganisasian (organizational strategy); (2) strategi penyampaian (delivery strategy); (3) strategi pengelolaan (management strategy).

Dalam kaitannya dengan pembelajaran PAI, strategi pengorganisasian adalah suatu metode untuk mengorganisasi isi bidang studi PAI yang dipilih untuk pembelajaran. Pengorganisasian isi bidang studi mengacu pada kegiatan pemilihan isi, penataan isi, pembuatan diagram, skema, dan sebagainya.

Strategi penyampain pembelajaran PAI adalah metode-metode penyampain pembelajaran PAI yang dikembangkan untuk membuat siswa dapat merespon dan menerima pelajaran PAI dengan mudah, cepat, dan menyenangkan. Karena itu, penataan strategi penyampain perlu menerima serta merespon masukan maupun pendapat siswa. Dengan demikian, strategi penyampain mencakup lingkungan fisik, guru atau orang, bahan-bahan pembelajaran, dan kegiatan-kegiatan yang berkaitan dengan pembelajaran yang lain. Dengan perkataan lain, media pembelajaran merupakan suatu komponen penting dan menjadi kajian utama dalam strategi ini. Strategi penyampaian ini berfungsi sebagai penyampai isi pembelajaran kepada siswa dan menyediakan informasi yang diperlukan untuk menampilkan unjuk kerja.

Menurut Martin dan Briggs (dalam Muhaimin) ada tiga komponen dalam strategi penyampain ini, yaitu: (1) media pembelajaran; (2) interaksi media pembelajaran dengan siswa; dan (3) pola atau bentuk belajar-mengajar. Media pembelajaran PAI mencakup semua sumber yang diperlukan untuk melakukan komunikasi dengan siswa. ${ }^{43}$

${ }^{43}$ Ibid., hlm. 152 
ISTIGHNA, Vol. 3, No 1, Januari 2020 P-ISSN 1979-2824 E-ISSN 2655-8459

Homepage: http://e-journal.stit-islamic-village.ac.id/index.php/istighna

Bahruddin Zaini

Pembelajaran Pendidikan Agama Islam Pada Program Akselerasi

Media pembelajaran dapat berupa apa saja yang dapat dijadikan perantara atau medium untuk dimuati pesan nilai-nilai pendidikan agama yang akan disampaikan kepada siswa. Media bisa berupa perangkat keras, seperti computer, televisi proyektor, orang atau alat dan bahan-bahan cetak lainnya. Media bisa berupa perangkat lunak yang digunakan pada perangkat keras tersebut. Dengan batasan Martin tersebut, guru PAI merupakan salah satu media pembelajaran PAI yang akan mengantarkan pesan nilai-nilai dan norma-norma ajaran Islam melalui pembelajaran yang direncanakan.

Dick dan Carey (1978) menyebutkan 4 faktor yang perlu dipertimbangkan dalam pemilihan media untuk suatu pembelajaran, disamping kesesuaian antara tujuan pembelajaran dengan media. Keempat faktor tersebut adalah sebagai berikut:

a) ketersediaan sumber dana setempat.

b) Tenaga dan fasilitas.

c) Kepraktisan dan ketahanan media yang akan digunakan.

d) Efektifitas biayanya dalam waktu yang panjang. ${ }^{44}$

Strategi pengelolaan pembelajaran adalah metode untuk menata interaksi antara guru dengan komponen-komponen metode pembelajaran lain. Strategi pengelolaan pembelajaran PAI berupaya untuk menata interaksi siswa dengan memperhatikan 4 hal, yaitu: Penjadwalan kegiatan pembelajaran yang menunjukkan tahap-tahap kegiatan yang harus ditempuh siswa dalam pembelajaran, Pembuatan catatan kemajuan belajar siswa melalui penilai yang komprehensif dan berkala selama proses pembelajaran berlangsung maupun sesudahnya, Pengelolaan motivasi siswa dengan menciptakan cara-cara yang mampu meningkatkan motivasi belajar siswa, dan kontrol belajar yang mengacu kepada pemberian kebebasan untuk memilih tindakan belajar dengan karakteristik siswa. ${ }^{45}$

${ }^{44}$ Muhaimin Dkk, op.cit., hlm. 97

${ }^{45}$ Ibid.,hlm. 101 
ISTIGHNA, Vol. 3, No 1, Januari 2020 P-ISSN 1979-2824 E-ISSN 2655-8459

Homepage: http://e-journal.stit-islamic-village.ac.id/index.php/istighna

Bahruddin Zaini

Pembelajaran Pendidikan Agama Islam Pada Program Akselerasi

3) Hasil Pembelajaran

Hasil pembelajaran mencakup semua akibat yang dapat dijadikan sebagai indikator perolehan nilai yang diperoleh sebagai akibat dari penggunaan metode pembelajaran di bawah kondisi pembelajaran yang berbeda. Hasil pembelajaran dapt berupa hasil nyata dan hasil yang diinginkan. Hasil nyata adalah hasil yang nyata dicapai dari penggunaan suatu metode di bawah kondisi tertentu, sedangkan hasil yang diinginkan adalah hasil yang ingin dicapai yang sering mempengaruhi keputusan perancang pembelajaran dalam melakukan pilihan metode yang sebaiknya digunakan. ${ }^{46}$

\section{KESIMPULAN}

Dapat di tarik kesimpulan bahwa perencanaan pembelajaran PAI pada program akselerasi di SD Lab UM harus melalui 3 tahapan (3P) yakni, Pertama, pelatihan tahap awal, Kedua proses (penyusunan), Ketiga prodak (pengembangan).

Pelaksanaan pembelajaran pendidikan agama islam pada program akselerasi di SD Lab UM, Mulai dari model pembelajaran hingga proses pembelajaran itu sendiri sudah terkonsep dengan mapan. Adapun dalam pemilihan model pembelajaran dan kegiatan pembelajaran guru PAI SD Lab UM harus memahami benar secara teoritis dan aplikasinya apakah model dan kegiatan pembelajaran tersebut dapat mengembangkan aspek-aspek bagi anak akselerasi, mulai dari aspek kognitif Afektif dan Psikomotorik.

Evaluasi program akslerasi di SD Lab UM sama seperti pelaksanaan evaluasi seperti program reguler dan evaluasi tingkat SD kebanyakan namun, proses evaluasi di SD Lab UM sedikit berbeda., Hal ini disebabkan sistem evaluasi yang berlandaskan karakteristik sekolah itu sendiri telah menuntun siswa lebih mandiri dan bertanggungjawab akan pekerjaannya. Peserta didik memposisikan

${ }^{46}$ Muhammad (Ed), op.cit., hlm. 31 
ISTIGHNA, Vol. 3, No 1, Januari 2020 P-ISSN 1979-2824 E-ISSN 2655-8459

Homepage: http://e-journal.stit-islamic-village.ac.id/index.php/istighna

Bahruddin Zaini Pembelajaran Pendidikan Agama Islam Pada Program Akselerasi

evaluasi sebagai kebutuhan baik secara akademik maupun mengukur tingkat keberhasilan selama pembelajaran.

\section{REFERENSI}

Ahmadi, Abu. . Dasar-Dasar Pendidikan Agama Islam. (Jakarta: Bumi Aksara. 2004)

Ahmadi, LifKhoirul, Pembelajaran Akselerasi Analisis Teori Dan Praktis Serta Pengaruh TerhadapMekanisme Dalam Kelas Akselerasi, (Jakarta: Prestasi Pustaka. 2011.)

Amin, Moh .Pengantar Ilmu Pendidikan Islam.(Pasuruan: PT Garuda Buana Indah. 1992.)

Djama'udin. “Memahami Psikologi Pendidikan Anak SD”. (Jakarta: Erlangga, 2001

Direktorat Pendidikan Dasar dan Menengah. Pedoman Penyelenggaraan Program Percepatan Belajar. (Jakarta: Departemen Pendidikan Nasional. 2003.)

Faisal, Sanapiah.Penelitian Kualitatif: Dasar-Dasar dan Aplikasi, (Malang: Yayasan Asah, Asih, Asuh, 1989)

Hamalik, Oemar. Kurikulumdan Pembelajaran. (Jakarta: BumiAksara. 2003.)

Hawadi, R.A (Ed). Akselerasi: A-Z Inforamasi Program Percepatan Belajar. (Jakarta: Grasindo Widiasarana Indonesia.2004.) dkk. Kurikulum Berdiferensiasi.(Jakarta: Grasindo Widiasarana Indonesia.2001.)

Majid, Abdul dan Andayani, Dian. Pendidikan Agama Islam Berbasis Kompetensi Konsep dan Implementasi Kurikulum. (Bandung: PT Rosda Karya2004.)

Mbulu, J. Pengajaran Individual: Pendekatan, Metode, dan Media, Pedoman Mengajar Bagi Guru dan Calon Guru. (Malang: Yayasan Elang Mas.. 2001)

Muhaimin. Paradigma Pendidikan Islam: Upaya Mengefektifkan Pendidikan Agama Islam di Sekolah.(Bandung: PT Remaja Rosdakarya Offset.2001.) 
ISTIGHNA, Vol. 3, No 1, Januari 2020 P-ISSN 1979-2824 E-ISSN 2655-8459

Homepage: http://e-journal.stit-islamic-village.ac.id/index.php/istighna

Bahruddin Zaini Pembelajaran Pendidikan Agama Islam Pada Program Akselerasi ,. Pengembangan Kurikulum PAI: di Sekolah, Madrasah dan Perguruan Tinggi.(Jakarta: PT Raja Grafindo Persada. 2005) , dkk. Strategi Belajar Mengajar: Penerapannya Dalam Pembelajaran Pendidikan Agama.(Surabaya. Citra Media.1996.)

Muhammad (Ed). Re-Formulasi Rancangan Pembelajaran Pendidikan Agama Islam.(Jakarta: Nur Insani. 2003)

Mulyasa, E. Kurikulum Berbasis Kompetensi. (Bandung: PT. Rosyda Karya.2004. Munandar, S.C.U. 1992. Mengembangkan Bakat dan Kreativitas anak Sekolah Penuntun bagi Guru dan Orang Tua. Jakarta: Gramedia.

Nasution, Kurikulim Dan Pengajaran.( Bandung, PT BumiAksara. 1989.)

RahmanArief , Catatan Guru Efektif Dalam Menghadapi Era GlobalisasiTahun, (Jakarta: GrasindoWidiasarana Indonesia. 2004)

Santoso, Gempur. Fundamental Metodoogi Penelitian Kuantitatif dan Kualitatif, (Jakarta: Prestasi Pustaka, 2005)

Siti.Rahayu,Psikologi Perkembangan.,( Yogyakarta:Gajah Mada University Press 2006,)

Sousa, D. A. How The Gifted Brain Learns, 2nd ed.( California: Corwin.2009).

Suryabrata, Sumadi. Metodologi Penelitian.(Jakarta: Raja Grafindo Persada.1998.)

Tirtonegoro, Sutratinah. Anak Supernormal Dan Prgram Pendidikannya Yotyakarta: BumiAksara.2001.

Triyono dkk,.Perkembangan Peserta Didik,(Malang: Fakultas Ilmu Pendidikan Universitas Negeri Malang.2012,)

Zuhairini dan Ghofir,Abdul. 2004. Metodologi Pembelajaran Pendidikan Agama Islam. Malang: UM Press. 